\title{
An Empire Development Board
}

$F^{\circ}$ OR some years past, Sir Robert Hadfield has advocated the establishment of an Empire Development Board in order to secure a systematic and co-ordinated or a 'planned' development of the vast resources and opportunities of the British Empire. He has now brought his suggestions together in a concise pamphlet* which, although prepared for consideration by a committee of the Institution of Civil Engineers, is deserving of the widest study. Sir Robert speaks with authority as a man of science, an engineer and as an administrator; and whilst drawing most of his examples from the field of engineering, he is clear that the membership of the Board should be fully representative of Empire scientific, technological and industrial activities.

The proposals are concrete and definite: a permanent body of adequately remunerated members continually at work and continually supplied with 'new blood' on an elastic basis of retirement by rotation, with a secretariat in each country and the main Board travelling frequently to all parts of the Empire. The Board would be non-political, and its aim would be to assist in developing new and additional resources, and not the guiding of existing trade into Empire channels by fiscal means. Its purpose would be to develop the Empire as a whole, and not to benefit one part at the expense of another. The Board would co-operate fully with all professional institutions, trade and industrial federations, as well as with the Governments of the constituent parts of the Empire, but would not itself control or manage existing or new undertakings.

* Empire Development and Proposals for the Establishment of an Empire Development Board. By Sir Robert Hadfleld. Pp. 78 . (London: Chapman and Hall, Ltd., 1935.) 28. 6d. net.
Sir Robert is under no illusions regarding the magnitude of such an undertaking. He points out, in the first place, however, that the Dominions Royal Commission (1912-17) expressed with no uncertain voice the need for such a body and unanimously recommended the creation of an Imperial Development Board. There is thus evidence both of need and of prospective co-operation. In reply to the argument that the plan is too immense to be handled effectively by any single organisation, it is urged that the magnitude of the task is simply a measure of the opportunity, and that clearly some organisation to deal with the problems is in any event better than no organ. isation at all. With regard to the objection that the cost would be excessive, it is argued that productive work would be accomplished at comparatively small cost and that within reasonable limits the more spent on the work the greater would be the return, whilst a small fraction of the sums spent annually on the various legislative bodies within the Empire would supply an adequate income.

The proposals put forward by Sir Robert Hadfield would seem to be especially vital at the moment. We have at home a National Government which has already indicated its appreciation of one urgent Empire problem by setting up a Dominions Migration Board. The countries of the Empire are united by a common loyalty and a real brotherhood which cannot be but strengthened by the work of a common Development Board. As one by one political ties are loosened, there is real need for a new bond.

L. D. S.

\section{Method and the Science of Man}

$I^{\mathrm{F}}$ F trenchant criticism of the methods employed in investigation affords any gauge of a healthy state in a given science, physical anthropology must be enjoying a peculiarly healthy activity. To recent attacks on racial classification on the basis of the measurement of physical characters may now be added criticism of both the accuracy and adequacy of bodily measurement itself. It may be remembered that Sir Arthur Keith was once criticised for relying on the evidence of the eye in racial discrimination. It was pointed out that in so doing he relied upon an inexact observation for evidence which was afforded more exactly by measurement. It should be remembered, however, that 'racial discrimination by inspection', to be effective, must be trained; while measurement itself, experience has shown, may be a source of error, if due precaution be not taken against the 
personal equation and any technical deficiencies of the observer.

Two recent studies in the methods of anthropoid palæontology and physical anthropology respectively lend support, however, to Sir Arthur's view. In a lecture on "Evolutionary Parallelism and Human Phylogeny", delivered recently before the Oxford University Anthropological Society, Prof. W. E. Le Gros Clark (Man, 2 ; 1936) stresses the implications of the principle of convergence, whereby a group, though splitting off from the main stock, might follow a course of parallel development, which would result in a close resemblance to members of the cognate stock, or stocks, while masking important differences, which the methods of anthropometry, in so far as they depend on a summation of resemblances, or craniometry, relying, more or less, on a single character, would inevitably overlook. These all-important differences are often of a non-metrical character. Such, for example, are the shape and orientation of the nasal skeleton; but they are not commonly taken into account in the biometrical treatment of the skull.

Prof. Le Gros Clark's reference to the nasal skeleton is of special interest in view of the fact that study of the nose is one of the principal sources of the data upon which Prof. V. Suk bases an attack on certain anthropometric methods, which constitutes the second of the studies to which reference is made above. In "Fallacies of Anthropological Identifications and Reconstructions" (Pub. de la Fac. des Sci. de l'Univ. Masaryk,
Brno, Čis 207 ; 1935) he shows that not only does facial expression not depend upon the osseous parts, but also that when an actual dissection is made, a very considerable discrepancy appears between anatomical points fixed through the tissues and those located on the actual bones themselves. Prof. Suk, working with cadavera, was able to fix these points with much greater accuracy than is possible in the living, yet even so he found in the difference before and after dissection an error of four, five and even six millimetres in locating the nasion; while the difference between the breadth of the external nose and that of the bony nose was sometimes so much as nineteen millimetres. One conclusion which emerges is that an index of the bony nose does not tell us anything about the external nose of the individual.

Taking into account the various points brought under consideration, Prof. Suk concludes that neither the reconstructions of early man-these he suggests are made under the influence of the Australian cast of countenance-nor the identifications of the bones of prominent historical characters by comparison of measurements with portraits, have any value. The further conclusion follows, in Prof. Suk's own words, "that that part of Anthropology, which is too much preoccupied with osteology and osteometry, loses any solid ground, when it does not take into consideration the whole body, for Man is not merely a skeleton".

\section{The Cost of Health}

Food, Health and Income:

Report on a Survey of Adequacy of Diet in relation to Income. By Sir John Boyd Orr. Pp. 72. (London : Macmillan and Co., Ltd., 1936.) 2s. 6d. net.

$\mathrm{I}^{\mathrm{N}}$ some of the recent controversial discussions concerning dietary standards applicable to human beings, attention was focused on minimum requirements. This report recently issued by Sir John Boyd Orr emphasises the need for defining the optimum diet, that is to say, one which is capable of maintaining a standard of perfect nutrition, which is "a state of well-being such that no improvement can be effected by a change in the diet". Although data do not yet exist for defining accurately this optimum diet, recent laboratory researches and dietary surveys have made it possible to indicate the amounts of some of the important constituents of a diet which are required to ensure good nutrition in certain classes of individuals. If such standards are accepted as furnishing an indication of the adequacy of present-day diets, it is possible to use existing data relating to the food consumption of the population of Great Britain to determine how far such diets are capable of supporting a state of good nutrition.

The mean quantity of each of the main varieties of food consumed by individuals in Great Britain could be calculated, and it would be a simple matter to determine whether this mean quantity 